\title{
Evaluation of existing Sustainable Infrastructure Rating Systems for their application in developing countries
}

\author{
Jose Manuel Diaz-Sarachaga $^{\mathrm{a}}$, Daniel Jato-Espino ${ }^{\mathrm{a}}$, Badr Alsulami $^{\mathrm{b}}$, Daniel Castro-Fresno $^{\mathrm{a}^{*}}$ \\ a GITECO Research Group, Universidad de Cantabria, Avd. de los Castros s/n, 39005 Santander (Spain) \\ ${ }^{b}$ Civil Engineering Department. Taif University, Taif - Al- Haweiah - P.O. Box 888 Zip Code 21974 (KSA) \\ E-mail addresses: jose-manuel.diazs@alumnos.unican.es (J.M. Diaz-Sarachaga); daniel.jato@unican.es (D. Jato- \\ Espino); b.alsulami@tu.edu.sa (B. Alsulami); daniel.castro@unican.es (D. Castro-Fresno) \\ * Corresponding Author: Tel: +34 942 201550; Fax: +34 942201703
}

\begin{abstract}
Several sustainable building rating systems were created worldwide during the last decades due to economic growth and the significance of environmental impact associated with the building industry. Similar infrastructure rating tools have started to be developed and implemented, being highly necessary to promote its development. Even though the existing sustainable infrastructure rating systems are focused on advanced economies, growing environmental concerns are increasing the need for new systems in the Developing World. This research analyses some of the mainstream infrastructure rating frameworks such as Envision (USA), Civil Engineering Environmental Quality (CEEQUAL) assessment (UK) and Infrastructure Sustainability (IS) Rating Tool (Australia) from the perspective of the Triple Bottom Line (economy, environment and society), in order to determine the effectiveness of their application in the context of the least developed countries. The analysis revealed that the three tools are biased towards the environmental dimension and are mainly oriented to developed countries. Consequently, the foundations on which these systems are based need to be further developed and enhanced to be of real relevance in poorer nations by balancing the weight of sustainable pillars, incorporating effective management guidelines and development goals set by United Nations declarations, and considering impacts beyond the single project framework.
\end{abstract}

\section{Keywords}

Triple Bottom Line; Infrastructure rating frameworks; Rating Systems; Sustainable Infrastructure; Developing countries.

\section{Introduction}

The Brundtland Commission Report defined Sustainable Development in 1987 as "development to meet the needs of the present without compromising the ability of future generations to meet their own needs" [1]. Sustainability is based on the balance of three key aspects named the Triple Bottom Line (TBL) [2]: Economics, Environment and Social responsibility. Economics seeks to fulfil the main goal of producing a long-term and positive economic impact, whilst Environment encourages organisations to benefit the planet as much as possible through sustainable practices, including the consideration of negative factors to the environment. Social responsibility aims to improve the lives of those with whom the projects interact. The well-being of users, workers, community members and other stakeholder interests should be considered as interdependent variables in Sustainability assessments [3]. As a consequence of the rising energy consumption and greenhouse gas emissions in the last century, which accounts for 30 and $40 \%$ of the total quantities for the building sector in developed countries [4], climate change has accelerated the development of international 
declarations and policies to preserve the environment and foster the use of assessment systems aimed at improving Sustainability.

Sustainability assessments have been defined as the processes of identifying, predicting and evaluating the potential impact of different initiatives and alternatives on the Triple Bottom Line (economy, environment and society) [5]. Furthermore, rating systems provide an effective framework for assessing environmental performance and integrating sustainable development into building and construction processes. They can be used as design tools by setting sustainable design priorities and goals, developing appropriate sustainable design strategies and determining performance measures to guide sustainable designs and decision makingprocesses [6, 7]. Amongst them, rating tools for buildings emerged more than two decades ago [8] in the UK and US before spreading worldwide. The most relevant are LEED (Leadership in Energy and Environmental Design) in the US [9], CASBEE (Comprehensive Assessment System for Building Environmental Efficiency) in Japan [10] and BREEAM (Building Research Establishment Environmental Assessment Method) in the UK [11]. The building industry boosted the utilisation of these systems primarily for commercial buildings in the US due to the greater quantity of resources required in relation to the whole sector: $72 \%$ of electricity consumption, $39 \%$ of energy use, $38 \%$ of carbon dioxide $\left(\mathrm{CO}_{2}\right)$ emissions [12], $40 \%$ of raw materials use, $30 \%$ of waste output and $14 \%$ of potable water consumption.

On the other hand, the use of assessment tools focused on major infrastructures has not been very common so far. Several score ratings have been developed by various public and private institutions to assess highways and roads, but only three of them (Envision in the USA [13], CEEQUAL in the UK [14] and the Infrastructure Sustainability (IS) Rating scheme in Australia [15]) are able to evaluate all types and sizes of civil infrastructures, including ports, airports, highways, dams, bridges, wastewater treatment facilities, tunnels and railways.

This research aims to compare and assess existing sustainable infrastructure rating tools to determine whether any of them can be effectively implemented in developing countries. The effect of urban development is examined under the perspective of its impact in the social and economic transformation of countries. Although green community frameworks are widely used to monitor the sustainable development of cities, infrastructure systems can provide a complementary tool to promote the balanced consideration of all TBL principles. Since most megacities are located in the least developed world, the implementation of infrastructure rating systems in these countries is a key factor to improve their sustainable development over the next decades. The article continues with a description and comparison of the three main existing infrastructure rating systems in terms of their compliance with sustainability, in order to identify the differences between developed and developing countries that need to be considered for their application in poorer economies. As a result, some principles and goals emanating from several United Nations Declarations, which seek to mobilize efforts through sustainable development worldwide, are suggested for incorporation into sustainable infrastructure frameworks.

\section{The effect of urban development on sustainability assessment systems}

The world is predominantly urban. $10 \%$ of the world's population inhabited urban areas at the beginning of the 20th century. By $2012,50 \%$ of the global population lived in urban areas, a percentage which is expected to rise to 70 per cent by 2050 [16]. Today, 3.6 billion urban dwellers are distributed unevenly among urban settlements of different sizes and more than 7 of every 10 urban residents in the world are found in developing countries. The level of urbanisation is expected to increase in all major areas of the developing world over the coming decades, with Africa and Asia urbanising more rapidly than the remaining continents [17]. The importance of urban areas is also confirmed by the diffusion of megacities of more than 20 million people, which are gaining ground mostly in the developing countries of Asia, Latin America and Africa [18]. 
Consequently, urbanisation will become a prominent trend over the next decades that should be meticulously considered in the assessment of sustainable development, in particular for poorer economies.

Urbanisation has the power to transform the social and economic fabric of countries. Cities are responsible for the biggest production and consumption of resources worldwide and are the main driver of economic growth and development, with about three-quarters of global economic activity coming from urban settlements. Urban population growth stimulates the urban share of global gross domestic product (GDP) and investment. The opportunity for development in countries can only be approached through sustainable urbanisation [19], which emphasises the economic and social importance of urban areas and also their poor environmental sustainability.

Urban projects promote the development of urban infrastructure through the encompassment of a very broad group of activities related to urban planning, urban design and architecture, transport studies, economics, ecology, geography, sociology, water management and engineering, waste management, energy engineering and economics, landscape planning and building architecture. Urban policy design is one of the most challenging problems for decision-makers because rapid urbanisation has increased the need for better governance of towns and cities. There are a number of different policy areas that need attention, including planning, housing and slum upgrading, land, energy and climate change, reconstruction and resilience, as well as infrastructure (transportation, water and sanitation), all of which should be added to the complexity of modern-day policy decision-making [20].

Sustainable urban development has become a powerful framework for developing solutions that improve the quality of life at a local level and can also be an important component to respond to the broader global environmental crises [21]. Urban planners have taken up the challenge of designing urban areas across the globe in ways that leave a smaller ecological footprint. Cultural values, education and citizen and community participation are all crucial aspects to consider when defining, measuring or implementing sustainable urban development policies and practices.

The difficulties in assessing sustainability in the urban environment are greater because of the lack of boundaries between the entities evaluated. Sustainability assessments at community and city scales are much more than the summation of individual green elements, because the scaling-up effect results in complex interactions that significantly alter the results obtained at building scale [22]. New frameworks for communities have been developed within the past years as an evolution of the sustainable building rating systems mentioned in the previous section in order to avoid the building scale factor. The most well-known systems are BREEAM Communities (Com) [23], CASBEE for Urban Development (UD) [24] and LEED for Neighbourhood Development (ND) [25].

BREEAM Com consists of forty individual assessment issues spanning five technical categories, plus a sixth category called "Innovation" for new and innovative technologies and practices. Each issue addresses a specific large-scale sustainability impact and is grouped within one of the five main technical categories: governance, land use and ecology, resources and energy, social and economic wellbeing and, transport and movement. Governance ensures the community involvement and leadership in the project, whilst land use and ecology improve biodiversity. The reduction of carbon emissions and use of natural resources is targeted by the resources and energy category, whereas healthy economy, socially cohesive community and the minimisation of impact on the health and wellbeing of inhabitants are goals sought by the social and economic wellbeing categories. Finally, the transport and movement category aims to create a safe and efficient transportation system for people and vehicles.

CASBEE UD considers two main kinds of criteria: performance and environmental loads. Performance criteria include factors such as the natural environment, quality of services and the contribution to the local community, 
whereas the environmental loads cover aspects related to impact on the local environment, social infrastructure and management of the local environment.

The LEED ND system rates neighbourhood development with at least two habitable buildings and an area no larger than 1,500 acres according to five categories: smart location and linkage (SLL), neighbourhood pattern and design (NPD), green infrastructure and buildings (GIB), innovation and design process (IDP) and regional priority credit (RPC). SLL encourages the development of existing communities and public transit infrastructure, fostering the improvement and redevelopment of existing urban spaces and limiting the expansion of the footprint. The conservation of land, the promotion of liveability, walkability and transportation efficiency and the reduction of public health risks by encouraging daily physical activities like walking and bicycling are assessed by NPF. GIB stimulates the design, construction and retrofit of buildings that use green building practices. IDP awards exemplary and innovative performance above and beyond the existing credits in the rating system, as well as the value of including an accredited professional in the design team, whilst RPC encourages projects to focus on earning credits related to the significance of the project to the local environment.

Another concept related to urban development that has taken hold in recent years is sustainable urban infrastructure [26]. This concept refers to infrastructure that facilitates the progress of a region towards the goal of sustainable living. Sustainable design can lead to the development of sustainable communities by ensuring that infrastructural knowledge provides improvements that do not deplete natural resources. Consequently, the transition toward and mass adoption of renewable resources feature heavily in sustainable infrastructure through public transport networks, the fostering of initiatives and programs for distributed generation and integrated energy demand management, high efficiency buildings, green buildings and sustainable habitats with energy-efficient landscaping, connected green spaces and wildlife corridors and low-impact development practices to protect water resources.

Community rating systems such as BREEAM Com, CASBEE UD and LEED ND align the principles of smart growth, new urban planning and green building into a set of standards for green design at the neighbourhood scale. These frameworks emphasize the key role of transportation efficiency in terms of infrastructure, which predominates over the utilities related to energy, IT and water and sanitation. The growing tendency in urban development, which currently focuses on environmental impact, is also starting to consider social and economic impact of expanding urban areas, setting aside liveability requirements in order to reinforce the role of the key sustainability principles. The least developed countries (LDCs) account for the greatest number of megacities in the world and will experience urbanization effects in the very short term over the next decades.

Envision, CEEQUAL and IS are complementary tools to community frameworks that provide effective stakeholder communication and engagement during the different life-cycle project stages, as well as the foundations for assessing sustainable community evolution. Furthermore, they encourage the implementation of project-based decision-making processes and management practices across the TBL to support the longterm interests of the community and provide a wider coverage of tools to stakeholders.

\section{Overview of mainstream Sustainable Infrastructure scoring systems}

The main features of the three mainstream Sustainable Infrastructure rating systems under analysis, namely CEEQUAL, Infrastructure Sustainability (IS) and Envision, are listed in Table 1. The next subsections detail the basis behind each of these scoring tools. 
Table 1. Summary of existing Sustainable Infrastructure rating tools

\begin{tabular}{|c|c|c|c|}
\hline Characteristics & $\begin{array}{l}\text { Civil Engineering Environment } \\
\text { Quality (CEEQUAL) (Version 5) }\end{array}$ & $\begin{array}{l}\text { Infrastructure Sustainability (IS) } \\
\text { (Version 1.0) }\end{array}$ & Envision (Version 2.0 Stage 2) \\
\hline Supporting Institution & CEEQUAL Itd & $\begin{array}{l}\text { Infrastructure Sustainability Council } \\
\text { of Australia (ISCA) }\end{array}$ & $\begin{array}{l}\text { Institute for Sustainable } \\
\text { Development (ISI) }\end{array}$ \\
\hline Geographical Context & UK \& Ireland / International & Australia \& New Zealand & USA \& Canada \\
\hline Year of launching & 2003 & 2012 & 2012 \\
\hline Manuals & $\begin{array}{l}\text { CEEQUAL for Projects / } \\
\text { CEEQUAL for Term Contracts }\end{array}$ & Infrastructure Sustainability (IS) & Envision \\
\hline Categories & 9 & 6 & 5 \\
\hline Sub-categories & 48 & 15 & 60 \\
\hline Levels of Achievement & $\begin{array}{l}4 \text { (Pass, Good, Very Good, } \\
\text { Excellent) }\end{array}$ & 3 (Commended, Excellent, Leading) & 4 (Bronze, Silver, Gold, Platinum) \\
\hline Awards & $\begin{array}{l}6 \text { (CEEQUAL for Projects) and } \\
2 \text { (CEEQUAL for Term Contracts) }\end{array}$ & 3 (Design, As Built, Operation) & 1 (Planning and Design) \\
\hline Verification Agents & $\begin{array}{l}\text { Independent CEEQUAL-trained } \\
\text { Verifiers }\end{array}$ & Independent ISCA-trained Verifiers & $\begin{array}{l}\text { ISI independent third-party } \\
\text { Verifiers }\end{array}$ \\
\hline
\end{tabular}

\subsection{Civil Engineering Environmental Quality (CEEQUAL)}

The Institution of Civil Engineers (ICE) led the development of CEEQUAL with financial support from the UK Government between 1999 and 2003. Relevant UK Government departments and agencies, civil engineering consultants, major contractors and professional and industry associations participated actively in the development of CEEQUAL. The tool was launched in September 2003 and became public in June 2004 after publishing Version 3 of the Assessment Manual for Projects. Since then, CEEQUAL has been updated until the latest Version 5.

CEEQUAL trained-assessors evaluate project/contract strategy and performance following a score scheme which includes a range of environmental and social issues arranged in nine sections and 48 sub-sections from the perspective of the three key stakeholders (Clients, Designers and Contractors) involved in the project (see Table 2). "Project Strategy" assesses the link between the project and sustainability, as well as its contribution to sustainable development. "Project Management" considers how sustainability issues are being incorporated into the overall project management. "People \& Communities" includes the assessment related to people affected by projects, the potential effects on the local population and the important actions of consultation and engagement with project stakeholders. The "Land use \& Landscape" category attempts to monitor the efficient use of land as a scarce resource. "The Historic Environment" comprises those buildings, structures and other features which have survived in the current landscape, townscape and seascape as evidence of environmental management over past centuries. "Ecology \& Biodiversity" takes into account concerns about the damage to wildlife habitats and the species that occupy them. "Water environment" aims to protect fresh and marine water bodies. "Physical Resources - Use \& Management" gives consideration to the responsible use of construction materials and how to deal with them at the end of their lifetime. Finally, "Transport" evaluates a wide range of effects such as land use changes, road accidents, air, noise and water pollution, as well as the consumption of resources. Four levels of achievement are considered in CEEQUAL: Pass (more than 25\%), Good (more than 40\%), Very Good (more than 60\%) and Excellent (more than 75\%). 
Table 2. Score of Civil Engineering Environmental Quality (CEEQUAL) rating system (Version 5)

\begin{tabular}{|c|c|c|c|c|}
\hline & Credit & Concept & Score & $\%$ \\
\hline & 1 & Project Strategy & 625 & 12.46 \\
\hline & 1.1 & Overall strategy for the project concept and design & 500 & 9.97 \\
\hline & 1.2 & Overall strategy for construction & 125 & 2.49 \\
\hline & 2 & Project Management & 545 & 10.87 \\
\hline & 2.1 & Basic Principles & 100 & 1.99 \\
\hline & 2.2 & Sustainability management & 160 & 3.19 \\
\hline & 2.3 & Contractual and procurement processes & 116 & 2.31 \\
\hline & 2.4 & Delivering performance on environmental and social aspects & 132 & 2.63 \\
\hline & 2.5 & Communicating sustainability performance & 37 & 0.74 \\
\hline & 3 & People and Communities & 530 & 10.57 \\
\hline & 3.1 & Brief and design & 66 & 1.32 \\
\hline & 3.2 & Consultation with stakeholders & 27 & 0.54 \\
\hline & 3.3 & Effects on local population and planning of mitigation measures & 44 & 0.88 \\
\hline & 3.4 & Implementation and monitoring during construction & 148 & 2.95 \\
\hline & 3.5 & Continuing engagement with relevant local interest groups & 74 & 1.48 \\
\hline & 3.6 & Effectiveness of the community engagement plan & 69 & 1.38 \\
\hline & 3.7 & Human environment, aesthetics and employment & 102 & 2.03 \\
\hline & 4 & Land use and landscape & 1004 & 20.02 \\
\hline & 4.1 & Basic principles on the use of land (above or below water) & 233 & 4.65 \\
\hline & 4.2 & Contamination of land and beds of the sea, estuaries, rivers \& lakes & 242 & 4.82 \\
\hline & 4.3 & Flood risk & 264 & 5.26 \\
\hline & 4.4 & Basic principles of landscapes issues & 55 & 1.10 \\
\hline & 4.5 & Landscape-related legal requirements & 85 & 1.69 \\
\hline & 4.6 & Implementation and management & 83 & 1.65 \\
\hline & 4.7 & Completion and aftercare & 42 & 0.84 \\
\hline & 5 & The historic environment & 230 & 4.59 \\
\hline & 5.1 & Baseline studies & 23 & 0.46 \\
\hline & 5.2 & Legal requirements, planning guidance and consultation & 17 & 0.34 \\
\hline & 5.3 & Conservation and enhancement & 141 & 2.81 \\
\hline & 5.4 & Information Dissemination and Public Access & 49 & 0.98 \\
\hline & 6 & Ecology and biodiversity & 315 & 6.28 \\
\hline & 6.1 & Basic Principles & 61 & 1.22 \\
\hline & 6.2 & Legal requirements & 76 & 1.52 \\
\hline & 6.3 & Conservation and enhancement of biodiversity & 79 & 1.57 \\
\hline & 6.4 & Habitat creation measures & 64 & 1.28 \\
\hline & 6.5 & Monitoring and maintenance & 35 & 0.70 \\
\hline & 7 & The water environment & 283 & 5.64 \\
\hline & 7.1 & Basic principles & 70 & 1.40 \\
\hline & 7.2 & Legal requirements & 24 & 0.48 \\
\hline & 7.3 & Protection of the freshwater and marine environments & 141 & 2.81 \\
\hline & 7.4 & Enhancement of the water environment & 48 & 0.96 \\
\hline & 8 & Physical resources - use and management & 1217 & 24.26 \\
\hline & 8.1 & Basic principles & 44 & 0.88 \\
\hline & 8.2 & Embodied impacts & 112 & 2.23 \\
\hline & 8.3 & Design for resource efficiency & 109 & 2.17 \\
\hline & 8.4 & Design for reduced energy consumption and carbon emissions in use & 97 & 1.93 \\
\hline & 8.5 & Energy and carbon performance on site & 109 & 2.17 \\
\hline & 8.6 & Water use & 291 & 5.80 \\
\hline & 8.7 & Responsible sourcing, re-use and recycling of materials & 106 & 2.11 \\
\hline & 8.8 & Minimising use and impacts of hazardous materials & 47 & 0.94 \\
\hline & 8.9 & Site waste management planning \& legal compliance & 89 & 1.77 \\
\hline & 8.10 & Waste and management of arisings & 213 & 4.25 \\
\hline & 9 & Transport & 267 & 5.32 \\
\hline & 9.1 . & Basic Principles & 65 & 1.30 \\
\hline & 9.2 & Operational Transport & 99 & 1.97 \\
\hline & 9.3 & Construction transport, including nuisance and disruption & 79 & 1.57 \\
\hline & 9.4 & Minimising workforce travel & 24 & 0.48 \\
\hline \multicolumn{3}{|r|}{ Total } & 5016 & 100 \\
\hline
\end{tabular}

CEEQUAL encompasses two different manuals: CEEQUAL for Projects and CEEQUAL for Term Contracts. CEEQUAL for Projects was specifically created for the assessment and rating of all types and scales of civil engineering, infrastructure, landscaping and public realm projects, including infrastructures associated with building developments. Depending on the location of the projects, the score is available in two editions: CEEQUAL for International Projects and CEEQUAL for UK \& Ireland Projects. The re-assessment of CEEQUAL weights is always recommended to reflect the adequacy and relevance of the credits included in the system according to the priorities of other countries, wherein the environmental, social and economic 
concerns can differ significantly from those considered for the UK. In the case of developing countries, social the level of human development in these countries, in order to appreciate their priorities and perceptions for infrastructure sustainability [27].

CEEQUAL for Projects has six types of Awards according to stakeholder involvement and the project stage considered in the application form. The Whole Project Award (WPA), jointly applied by or on behalf of the Client, Designer and Principal Contractor(s), is verified and awarded at the end of construction, whilst the Whole Project Award with an Interim Client \& Design Award enables the project team to undertake an assessment during the design stage of WPA, which is superseded once the project and the WPA are completed. The Client \& Design Award implies a joint application by the client and designer before the start of construction, whilst the Design Award is only for principal designer(s). Finally, the Design \& Build Award exclusively involves the contractor and designer(s), whereas the Construction Award is only for principal contractor(s).

CEEQUAL for Term Contracts was specifically developed for the assessment of civil engineering and public realm works that are undertaken through contracts over several years, also being suitable for projects which include the construction of new works based on many small-scale and repetitive operations. CEEQUAL for Term Contracts is presented in two Assessment Manual editions, Maintenance and Construction of small or repetitive new works considering only two Awards: The Whole Team Award \& Assessment and the Delivery Award \& Assessment, when evaluations are respectively undertaken by the main contractor(s) and designers without client involvement. In the latter case, assessments are performed in the first and penultimate years of the contract after annual visits of the CEEQUAL Verifier before contract completion.

\subsection{Infrastructure Sustainability (IS) Rating Tool}

As a consequence of the presentation given in February 2007 to Engineers Australia by David Hood and Glenn Hedges, entitled "Does Australia Need an Environmental Rating Scheme for Non-Building Projects", a Steering Committee was formed in March 2007 with the main goal of investigating other existing international rating systems to initiate the creation of a local scheme. The Australian Green Infrastructure Council (AGIC) was created and registered in February 2008 to develop the rating tool, which was concluded in 2011 after undertaking different trials and weighting surveys. The Infrastructure Sustainability (IS) Rating Tool Version 1.0 was released nationally in 2012, a year in which AGIC was renamed the Infrastructure Sustainability Council of Australia (ISCA).

Table 3 shows the IS rating scheme Version 1.0, which consists of 15 Categories organised in 6 topics. The rating tool is based on three performance levels: Design, Build and Operation ratings. A Design rating can be awarded after the inclusion of sustainable elements and construction requirements in the project's design. Once the planning and design phases are completed, requirements for sustainability and performance during construction are assessed. The Build rating is awarded after the end of project construction and replaces the Design rating. In order to be awarded an Operation rating, the asset must have completed at least a period of twenty-four months of operation. Achieving Design or Build ratings is not a requirement for Operation rating. Three levels of achievement are considered by the IS rating tool: Commended ( 25 to 50 points), Excellent (50 to 75 points) and Leading (75 to 105). 
Table 3. Score of Infrastructure Sustainability (IS) Rating Tool (Version 1.0)

\begin{tabular}{|c|c|c|c|}
\hline Credit & Concept & Score & $\%$ \\
\hline 1 & Management and Governance & 20.5 & 19.52 \\
\hline 1.1 & Management Systems & 10.50 & 10.00 \\
\hline 1.2 & Procurement and Purchasing & 5.00 & 4.76 \\
\hline 1.3 & Climate Change Adaptation & 5.00 & 4.76 \\
\hline 2 & Using Resources & 24.5 & 23.33 \\
\hline 2.1 & Energy and Carbon & 10.50 & 10.00 \\
\hline 2.2 & Water & 7.00 & 6.67 \\
\hline 2.3 & Materials & 7.00 & 6.67 \\
\hline 3 & Emissions, Pollution and Waste & 24.5 & 23.33 \\
\hline 3.1 & Discharge to air, land and water & 10.50 & 10.00 \\
\hline 3.2 & Land & 7.00 & 6.67 \\
\hline 3.3 & Waste & 7.00 & 6.67 \\
\hline 4 & Ecology & 10.50 & 10.00 \\
\hline 4.1 & Ecology & 10.50 & 10.00 \\
\hline 5 & People and Place & 20.00 & 19.05 \\
\hline 5.1 & Community Health, Well-being and Safety & 5.00 & 4.76 \\
\hline 5.2 & Heritage & 5.00 & 4.76 \\
\hline 5.3 & Stakeholder Participation & 5.00 & 4.76 \\
\hline 5.4 & Urban and Landscape Design & 5.00 & 4.76 \\
\hline 6 & Innovation & 5.00 & 4.76 \\
\hline 6.1 & Innovation & 5.00 & 4.76 \\
\hline & Total & 105.00 & 100.00 \\
\hline
\end{tabular}

\subsection{Envision Sustainable Infrastructure rating system}

Envision was created by a strategic alliance of the Zofnass Program for Sustainable Infrastructure at the Harvard University Graduate School of Design and the Institute for Sustainable Infrastructure (ISI). ISI launched the Envision Version 2.0 in 2012. Similar to its building counterpart (LEED), this planning and design guidance tool provides industry-wide sustainability metrics for all infrastructure types.

Envision Version 2.0 Stage 2 has 60 sustainability credits consisting of a series of yes/no questions arranged in five categories that address major impact areas in terms of the Triple Bottom Line pillars (see Table 4). Envision provides innovation points for projects with advanced sustainable infrastructure practices or exceptional performance beyond expectations. Five levels of achievement are defined by Envision to assess performance and foster project improvement: Improved (performance is above conventional); Enhanced (sustainable performance adheres to Envision principles); Superior (sustainable performance is noteworthy); Conserving (performance results in zero impact); and Restorative (performance restores natural or social systems). There are 4 Envision award levels according to the percentage of credits obtained: Bronze (20 to $30 \%$ ), Silver Award (30 to 40\%), Gold Award (40 to 50\%) and Platinum Award (over 50\%). 
Table 4. Score of Envision Sustainable Infrastructure rating system (Version 2.0 Stage 2)

\begin{tabular}{|c|c|c|c|c|c|c|c|c|c|c|c|}
\hline Credit & Concept & Improved & $\%$ & Enhanced & $\%$ & Superior & $\%$ & Conserving & $\%$ & Restorative & $\%$ \\
\hline 1 & Quality of Life & 13 & 16.46 & 27 & 15.17 & 62 & 17.46 & 150 & 21.43 & 151 & 29.38 \\
\hline 1.1 & Purpose & 4 & 5.06 & 9 & 5.06 & 20 & 5.63 & 45 & 6.43 & 56 & 10.89 \\
\hline 1.2 & Community & 6 & 7.59 & 12 & 6.74 & 23 & 6.48 & 70 & 10.00 & 52 & 10.12 \\
\hline 1.3 & Wellbeing & 3 & 3.80 & 6 & 3.37 & 19 & 5.35 & 35 & 5.00 & 43 & 8.37 \\
\hline 2 & Leadership & 10 & 12.66 & 31 & 17.42 & 56 & 15.77 & 115 & 16.43 & 31 & 6.03 \\
\hline 2.1 & Collaboration & 5 & 6.33 & 17 & 9.55 & 33 & 9.30 & 60 & 8.57 & 0 & 0.00 \\
\hline 2.2 & Management & 2 & 2.53 & 6 & 3.37 & 13 & 3.66 & 25 & 3.57 & 31 & 6.03 \\
\hline 3 & Resource Allocation & 29 & 36.71 & 66 & 37.08 & 112 & 31.55 & 170 & 24.29 & 62 & 12.06 \\
\hline 3.1 & Materials & 15 & 18.99 & 34 & 19.10 & 59 & 16.62 & 80 & 11.43 & 0 & 0.00 \\
\hline 3.2 & Energy & 7 & 8.86 & 16 & 8.99 & 25 & 7.04 & 45 & 6.43 & 20 & 3.89 \\
\hline 3.3 & Water & 7 & 8.86 & 16 & 8.99 & 28 & 7.89 & 45 & 6.43 & 42 & 8.17 \\
\hline 4 & Natural Word & 15 & 18.99 & 33 & 18.54 & 86 & 24.23 & 165 & 23.57 & 169 & 32.88 \\
\hline 4.1 & Siting & 8 & 10.13 & 17 & 9.55 & 49 & 13.80 & 80 & 11.43 & 74 & 14.40 \\
\hline 4.2 & Land \&Water & 2 & 2.53 & 10 & 5.62 & 23 & 6.48 & 40 & 5.71 & 39 & 7.59 \\
\hline 5 & Climate & 12 & 15.19 & 21 & 11.80 & 39 & 10.99 & 100 & 14.29 & 101 & 19.65 \\
\hline 5.1 & Emission & 6 & 7.59 & 13 & 7.30 & 13 & 3.66 & 30 & 4.29 & 40 & 7.78 \\
\hline \multirow[t]{2}{*}{5.2} & Resilience & 6 & 7.59 & 8 & 4.49 & 26 & 7.32 & 70 & 10.00 & 61 & 11.87 \\
\hline & Total & 79 & 100.00 & 178 & 100.00 & 355 & 100.00 & 700 & 100.00 & 514 & 100.00 \\
\hline
\end{tabular}

Even though ISI does not consider economic assessments, some of its Chartered members have created some tools for that purposes, such as Business Case Evaluator, PRISM, Sustainable Return on Investment (SROI) and the Zofnass Economic Process Tool. Business Case Evaluator provides a value-based and riskadjusted analysis of storm-water infrastructure projects and maps. PRISM is an evaluation tool used for evaluating Triple Bottom Line factors using risk-based dollar equivalents. SROI is a framework to measure the Triple Bottom Line impacts of a project that determines the full value of a project and develops tangible metrics to assess the total investment value. Finally, the Zofnass Economic Process Tool offers a way to quantify sustainability impacts in infrastructure projects based on Envision.

\section{Discussion}

In the previous section, the three main existing sustainable infrastructure rating tools have been briefly described, including their backgrounds, score schemes of current versions and levels of achievement and awards. In this context, the aim of this section is to evaluate the suitability of these frameworks in developing countries. To this end, the main aspects to consider for the application of infrastructure rating tools in these countries is discussed and the existing sustainable infrastructure systems are compared and reviewed in terms of the TBL, in order to evaluate their applicability in developing countries according to the United Nations Declaration.

\subsection{Developing countries in the context of Sustainable Infrastructure Rating Tools}

There are different considerations in developed and developing countries in terms of the needs to be covered by sustainable infrastructure rating tools, mainly due to different national priorities and strategies. This section enumerates special features of poorer economies in comparison with advanced ones which must be considered in the assessment of existing frameworks for their application in developing countries.

The Human Development Index (HDI) is a composite statistic of life expectancy, education and income per capita used by the United Nations to rank countries, such that those countries with a HDI below 0.8 are considered developing countries [28]. Nations with low human development indices are likely to emphasise paternalistic socio-economic development instead of environmental aspects when formulating their sustainability agenda in the short to medium term [27]. Social priorities are associated with the stimulation of micro-economic activities and the capacity of building through the generation of employment and other interventionist socio-economic policies. 
Developing countries require a major increase in infrastructure investment to reduce growth constraints, contribute to urbanisation needs and meet their development, inclusion and environmental goals. Global trade plays an important role in the development of countries and consequently in infrastructure. This includes traditional transport infrastructure such as roads, railways, ports and information technology infrastructure. The investment budget is predicted to rise from the current level of $\$ 1$ trillion per year to approximately $\$ 1.8-2.3$ trillion per year by 2020 , assuming $4 \%$ of annual growth rate of the Gross Domestic Product (GDP), which means about 3-8\% of total GDP. An additional $\$ 200-300$ billion is also destined to measures aimed at ensuring lower emissions and more resilience to climate change [29].

The concentration of world population in cities and the rapid growth of the number of megacities in the world, which are phenomena mainly located in developing countries, emphasise the key role of infrastructure in urban development in order to achieve the goal of sustainable living. Urban settlements as the main driver of economic growth and development require particular attention to be paid to social and economic aspects without neglecting environmental issues. The development of sustainability in urban areas requires a balance among urban development, environmental protection and the specific demands of citizens (incomes, employment, shelter, basic services, social infrastructure and transportation) [30].

Stakeholders in less developed economies often allocate different weights to different sustainability areas depending on the prevailing problems in society. Some indicators such as health and safety are vulnerable to shifts in the definition and prioritisation of the core elements of sustainability by society. However, this approach raises some issues related to intergenerational priorities in sustainability and the subsequent associated risks, which makes the design of sustainability risk management strategies necessary.

Developing countries prefer indicators that are measured based on their compliance with statutory and regulatory provisions. Consequently, the existing approach to enforce sustainability practices is predominantly accomplished through command and control structures in the form of ordinances and statutory guidelines. A better and more efficient approach might consist of the establishment of responsible sustainability practices driven by economic forces.

The temporal space-time dimension of sustainability necessitates the development of generic but flexible decision support tools that facilitate the selection of indicators based on country and location-specific needs through the study of the local priorities in relation to the sustainability agenda and the incorporation of international indicators. Developing countries subscribed to internationally accepted sustainability metrics need to address their local situation as a part of overall international development strategies. Sustainable infrastructure rating systems are suggested as useful frameworks to implement and monitor sustainable performance indicators and green infrastructure practices in these countries.

\subsection{Comparison of mainstream Sustainable Infrastructure Rating Systems}

There are many commonalities among Envision, CEEQUAL and IS to ensure and assess sustainability in infrastructure projects. Although they all include the main aspects of sustainability emphasising particular criteria, the boundaries that delimit whether a project is sustainable or not are not clearly defined. Process and outcome assessments are often mixed in these approaches, which also have differences in the way in which they address the different sustainability needs that appear at different stages of project life-cycle. Furthermore, the importance given to management by these systems in the sustainability assessment is very unequal [31].

Table 5 summarises the main criteria of the examined sustainable infrastructure rating systems. The environmental dimension is mostly considered through very common aspects such as GHG emissions, habitats and biodiversity preservation, pollution (air, lighting, noise and water), energy consumption (renewable 
resources and efficiency), flooding risk, land use and more efficient resource management. These frameworks deal with the social dimension through general community issues such as stakeholders' engagement, communication, health, well-being and historical and cultural heritage. Management covers further aspects such as procurement, project and risk management, decision-making processes and regulations and policies. Finally, the economic pillar focuses on workforce conditions, sustainable growth and development, improvement of the community's quality of life and connectivity.

Table 5. Main criteria considered by the rating systems under assessment

\begin{tabular}{|c|c|c|c|}
\hline Economy & Environment & Society & Management \\
\hline Minimising workforce travel & Principles on the use of land & $\begin{array}{l}\text { Stakeholders \& Community } \\
\text { engagement }\end{array}$ & $\begin{array}{l}\text { Project Management (design, } \\
\text { construction, contract) }\end{array}$ \\
\hline Increase of community's & Flood risk management & & \\
\hline connectivity & Maintenance, enhancement or & $\begin{array}{l}\text { Assessment of impacts in } \\
\text { neighbours }\end{array}$ & $\begin{array}{l}\text { Sustainable procurement } \\
\text { management }\end{array}$ \\
\hline Employment growth & restoration of biodiversity and & & \\
\hline & habitats & Promotion of local employment & Decision-making processes \\
\hline Resource efficiency & & & \\
\hline Business development & $\begin{array}{l}\text { Maintenance or enhancement of } \\
\text { landscapes }\end{array}$ & $\begin{array}{l}\text { Historical, cultural and } \\
\text { archaeological heritage }\end{array}$ & $\begin{array}{l}\text { Risk and Opportunity } \\
\text { management }\end{array}$ \\
\hline Procurement practices & Efficient water use & Increase in public information & $\begin{array}{l}\text { Conflicting regulations and } \\
\text { policies }\end{array}$ \\
\hline Workforce development & $\begin{array}{l}\text { Maintenance or enhancement of } \\
\text { water quality }\end{array}$ & $\begin{array}{l}\text { Promotion of community health, } \\
\text { well-being and safety }\end{array}$ & \\
\hline $\begin{array}{l}\text { Stimulation of sustainable } \\
\text { growth and development }\end{array}$ & Reduction of GHG emissions & Workforce safety & \\
\hline \multirow{7}{*}{$\begin{array}{l}\text { Improvement of community } \\
\text { Quality of Life }\end{array}$} & Noise management & Focus on accessibility & \\
\hline & Reduction of Air pollutants & Enhancement of public space & \\
\hline & Lighting pollution management & $\begin{array}{l}\text { Preservation of views and local } \\
\text { character }\end{array}$ & \\
\hline & Reduction of energy use & & \\
\hline & Promotion of renewable energy & & \\
\hline & Efficient resource management & & \\
\hline & $\begin{array}{l}\text { Hazardous materials } \\
\text { management }\end{array}$ & & \\
\hline
\end{tabular}

All points awarded by the tools can be grouped into the three sustainable pillar categories as shown in Table

6. Only the superior level of achievement has been considered for Envision, because its sustainable performance is similar to CEEQUAL and IS systems. The share of points awarded by CEEQUAL, IS and Envision included in Table 6 reveals that all systems are fundamentally dominated by an environmentallybased approach. The average trend in the three systems reflects that Environment is the most relevant category with around two thirds of the total score, whilst Society and Economy represent around $20 \%$ and $10 \%$ of points, respectively. This unbalanced integration of the sustainability dimensions may lead to the promotion of weak sustainability [32].

Table 6. Share of Triple Bottom Line pillars score

\begin{tabular}{|c|c|c|c|c|c|c|c|c|}
\hline \multirow{2}{*}{ Rating System } & \multicolumn{2}{|c|}{ Economy } & \multicolumn{2}{|c|}{ Environment } & \multicolumn{2}{|c|}{ Society } & \multicolumn{2}{|c|}{ Total } \\
\hline & Points & $\%$ & Points & $\%$ & Points & $\%$ & Points & $\%$ \\
\hline CEEQUAL & 515.66 & 10.28 & 3140.16 & 62.6 & 1360.16 & 27.12 & 5016 & 100 \\
\hline Infrastructure Sustainability (IS) & 13 & 12.38 & 74 & 70.48 & 18 & 17.14 & 105 & 100 \\
\hline Envision Superior & 29.64 & 8.35 & 253.64 & 71.46 & 71.64 & 20.18 & 355 & 100 \\
\hline
\end{tabular}

The score thresholds leading to the different levels of achievement established by the three systems show that limits are approximately equally set in CEEQUAL and the IS rating system, whilst Envision Superior displays 
with around $75 \%$ of all points, Envision, which only needs $50 \%$ of those points, puts a strong focus on some criteria (e.g. restorative actions) that can make it even more demanding in some ways.

\subsection{Assessment of Sustainable Infrastructure Rating Systems for their application in developing countries according to the United Nations Declarations}

The United Nations Conference on Environment and Development held in Rio de Janeiro in 1992 [33] reaffirmed the Declaration of the United Nations Conference on the Human Environment, adopted in Stockholm on 16 June 1972, which established a new and equitable global partnership through the creation of new levels of cooperation among states, key sectors of societies and people, in order to subscribe international agreements that respect the interests of all and protect their integrity worldwide. Amongst the 27 principles proclaimed in that Declaration, principles 11 and 22 directly affect sustainable infrastructure rating systems. Principle 11 declares that states shall enact effective environmental legislation, so that environmental standards, management objectives and priorities should reflect the environmental and development context to which they apply. Standards applied by some countries may be inappropriate and of unwarranted economic and social cost to developing countries. CEEQUAL is capable of scoring projects worldwide by undertaking an analysis that ensures the system reflects the needs of the country in question and modifies the UK baseline scheme through the re-assessment of weights. In contrast, Envision and IS are exclusively oriented to their geographical context: North America (US and Canada) and Australia and New Zealand, respectively. In order to be in line with the terms of principle 11, the three systems should include all the sustainable priorities and needs for the countries where they will be applied. Similarly, principle 22 states that indigenous people and other local communities have a vital role in environmental management and development because of their knowledge and traditional practices. States should recognise and support their identity, culture and interests and enable their participation in the achievement of sustainable development [33].

As shown in Table 5, CEEQUAL, IS and Envision rating systems omit significant aspects in the social dimension such as equal opportunities, organisational capacities and education, poverty or indigenous communities. The UN Millennium Declaration [34] sets out a framework of 8 goals, 18 targets and 48 indicators to measure progress towards the Millennium Development Goals (MDGs) with a deadline of 2015 (see Table 7). At the end of this period, this document was superseded by the 2030 Agenda for Sustainable Development [35], which sets forth an action plan with 17 Sustainable Development Goals (SDGs) and 169 targets, in order to enhance the scope of MDGs. The MDGs approach was adopted by experts from the United Nations, the International Monetary Fund, the Organisation for Economic Co-operation and Development (OECD) and the World Bank. Even though MDGs involve problems common to all countries worldwide, the pronounced disparities between developed and the least developed nations lead to paying much more attention to their achievement in the latter. Amongst all Millennium Development Goals, some targets of Goals $1,3,7$ and 8 should also be covered by the rating systems for infrastructure projects in developing countries. The remaining MDG goals are oriented to education and health issues. 
Table 7. Millennium Development Goals (MDGs)

\begin{tabular}{llll}
\hline G\# & Goal & T\# & Target \\
\hline 1 & $\begin{array}{l}\text { Eradicate extreme Hunger and } \\
\text { Poverty }\end{array}$ & 1 & Halve the proportion of people whose income is less than $\$ 1$ a day \\
& 2 & Halve the proportion of people who suffer from hunger
\end{tabular}

$2 \quad$ Achieve Universal Primary Education Ensure that children everywhere, boys and girls alike, will be able to complete a full course of primary schooling

$3 \quad$ Promote Gender Equality and Empower Women Eliminate gender disparity in primary and
and in all levels of education before 2015

$4 \quad$ Reduce Child Mortality

$5 \quad$ Reduce by two-thirds the under-five mortality rate

$5 \quad$ Improve Maternal Health

$6 \quad$ Reduce by three-quarters the maternal mortality ratio

\begin{tabular}{llll}
\hline 6 & Combat HIVIAIDS, Malaria and & 7 & Have halted and begun to reverse the spread of HIVIAIDS by 2015
\end{tabular} other disease

8 Have halted and begun to reverse the incidence of malaria and oth major diseases

$7 \quad$ Ensure Environmental Integrate the principles of sustainable development into countries'
policies and programs and reverse the loss of environmental resources Sustainability

Halve the proportion of people without sustainable access to safe

11 Have achieved by 2020 a significant improvement in the lives of at least 32 100 million slum dwellers

$8 \quad$ Develop a Global Partnership for $12 \quad$ Develop further an open, rule-based, predictable, non-discriminatory 33 Development

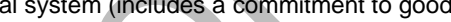
internationally) Address the special needs of the Least Developed Countries (includes tariff- and quota-free access for Least Developed Countries, exports, enhanced program of debt relief for heavily indebted poor countries and 37 cancellation of official bilateral debt, and more generous official development assistance for countries committed to poverty reduction) 14 Address the special needs of landlocked developing countries and

15 Deal comprehensively with the debt problems of developing countries masures in order to make debt sustainable in the long term

16 In cooperation with developing countries, develop and implement strategies for decent and productive work for youth

17 In cooperation with pharmaceutical companies, provide access to affordable essential drugs in developing countries

18 In cooperation with the private sector, make available the benefits of new technologies, especially information and communications technology

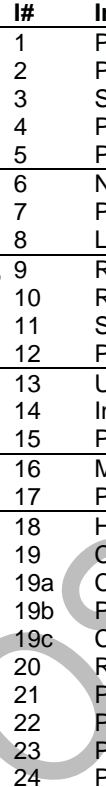

Indicator

Proportion of population below $\$ 1$ per day

Poverty gap ratio (incidence $x$ depth of poverty)

Share of poorest quintile in national consumption

作

Proportion of population below minimum level of dietary energy consumption

Proportion of pupils starting grade 1 who reach grade 5

Ratio of girls to boys in primary, secondary and tertiary education

Ratio of literate women to men, 15-24 years old

Share of women in waged employment in the non-agricultural sector

Proportion of seats held by women in national parliament

Under-five mortality

Proportion of 1 year-old children immunized against measles

Maternal mortality ratio

Proportion of births attended by skilled health personnel

HIV prevalence among pregnant women aged 15-24 years

Condom use rate of the contraceptive prevalence rate

Condom use at last high-risk sex

Percentage of population aged 15-24 with comprehensive correct knowledge of HIVIAIDS

Contraceptive prevalence rate

Ratio of school attendance of orphans to school attendance of non-orphans aged 10-14

Prevalence and death rates associated with malaria

Provalence and death rates associsted with tuberculosis

Proportion of tuberculosis cases detected and cured

Proportion of land area covered by forest

Ratio of area protected to maintain biological diversity to surface area

Carbon dioxide emissions per capita and consumption of ozone-depleting CFCs

Proportion of population using solid fuels

Proportion of population with access to an improved water source, urban and rura

Proportion of population with access to improved sanitation, urban and rural

Proportion of households with access to secure tenure

Net Official Development Assistance (ODA), total and to LDCs, as percentage of OECD/Development Assistance Committee (DAC) donors' gross national income (GNI)

Proportion of total bilateral, sector-allocable ODA of OECD/DAC donors to basic social services (basic education, primary health care, nutrition, safe water and sanitation)

Proportion of bilateral ODA of OECD/DAC donors that is untied

ODA received in landlocked developing countries (LDCs) as a proportion of their GNIs

ODA received in small developing island States as a proportion of their GNIs

Proportion of total developed country imports (by value and excluding arms) from developing countries and from LDCs, admitted free of duty.

Average tariffs imposed by developed countries on agricultural products and textiles and clothing from developing countries

Agricultural support estimate for OECD countries as percentage of their GDP

(Heir Heavily Indebted Poor Countries Initiative (HIPC)

decision pints and number that have reached their HIPC completion points

Debt relief committed under HIPC initiative

Debt service as a percentage of exports of goods and services

Unemployment rate of young people aged 15-24 years, each sex and total

47 Proportion of population with access to affordable essential drugs on a sustainable basis

48 Telephone lines and cellular subscribers per 100 population Personal computers in use per 100 population and Internet users per 100 population 
Goal 1 ("Eradicate Extreme Poverty \& Hunger") targets halving the proportion of people whose income is less than $\$ 1$ per day and the proportion of people who suffer from hunger. Rating systems can contribute to monitoring the economic effect of projects in the reduction of poverty through the extensive use of local manpower and supplies to promote local sustainable growth. Goal 3 ("Promote Gender Equality and Empower Women") seeks the elimination of gender disparity in primary and secondary education, preferable by 2005, and at all levels of education before 2015. The increasing and gradual incorporation of women into the labour market should be accompanied by policies of equal gender education and wages, reinforcing the role of women in society.

Goal 7 ("Ensure Environmental Sustainability") aims to integrate the principles of sustainable development into countries' policies and programs and reverse the loss of environmental resources. In addition, it intends to halve the proportion of people without sustainable access to safe drinking water and basic sanitation. Effective management frameworks are highly necessary to address sustainable development, where basic sanitation and drinking water are the main priorities. Goal 8 ("Develop a Global Partnership for Development") targets developing a financial system to improve governance and address special needs of poorer economies such as debt problems, youth employment, poverty reduction and access to benefits of new technologies.

From the economic perspective, there are three relevant subjects that should also be deeply considered and incorporated into the three analysed sustainable infrastructure rating systems: the evidence that projects support sustainable growth and economic development, the financial viability of projects and their contribution to the reduction of poverty as stated in Millennium Development Goal 1 . Whilst sustainable growth and economic development issues are taken into account in some Envision credits such as QL 1.1, QL 1.2 and QL 1.3, CEEQUAL and IS systems omit the meaningful economic subjects above mentioned.

The lack of definitive management guidelines to establish key elements that constitute a sustainable project often confuses project owners, consultants and other stakeholders. Some of them apply their own notions about sustainable development based on their particular interests through some newly created systems. However, most of them do not provide an effective connection between the overall goals of sustainable development and the projects that move society towards these goals. The implementation of sustainability management and reporting systems is crucial in order to meet project goals for sustainable development and measure progress towards the goals, while describing performance through a series of sustainability factors such as economic, environmental, social and corporate governance performances [36].

The addition of these relevant subjects to infrastructure frameworks contributes to balancing the relevance of the three sustainable pillars in the achievement of sustainable development goals, in particular in developing countries where these factors play a much more crucial role than in developed economies. Sustainable procurement describes the consideration of environmental, social and economic parameters in addition to the conventional ones of cost, time and quality for selecting suppliers and service providers. These considerations require that suppliers report the sustainability impact of the materials and products they offer, such as the consumption of waste, carbon and water, the contribution to the local economy through the use of local labour and the incorporation of sustainability criteria in the local community engagement process.

Designers and contractors also collaborate with suppliers to deliver the final product according to required sustainability standards. Pre-qualification of consultants, designers or contractors is highly recommended to minimize risks during the procurement process. Even though the CEEQUAL, Envision and IS rating tools include best sustainable procurement practices, they should promote their extensive use through an effective combination with project management practices to enhance the contribution to social and economic dimensions.

\section{Conclusions}


This article analyses the suitability of current sustainable infrastructure rating systems, namely CEEQUAL, Envision and IS, by taking into account some factors that can affect sustainability assessment in the least developed countries, such as the effect of urban development, the particular context of developing countries and the United Nations Declarations related to international development. The main conclusions drawn from this study are summarized as follows:

- The three available infrastructure tools analysed are biased towards environmental concerns in detriment of the economic and social dimensions, which are a top priority for developing countries, where the promotion of economic growth and sustainable living is a prevailing goal. Furthermore, existing frameworks are mainly oriented to advanced economies where they were originally launched. Therefore, an exercise in understanding and incorporating priorities and needs of poorer economies into current systems is highly necessary to validate their successful implementation in these geographical areas.

- Management is arisen as the fourth pillar to support the Triple Bottom Line. The lack of definitive management frameworks requests the implementation of a wide range of guidelines related to project \& risk management and sustainable procurement that can enhance the contribution of project stakeholders. These directives should be accompanied by effective reporting systems and suitable metrics and indicators based on the needs of poorer countries that are able to monitor and measure progress towards sustainable goals.

- Although some green building rating tools such as BREEAM Communities, CASBEE for Urban Development and LEED for Neighbourhood Development are widely employed to assess the degree of sustainable development of communities and cities, sustainable infrastructure frameworks can also complement them through the balanced consideration of the Triple Bottom Line.

- The principles proclaimed in the Declaration of the United Nations Conference on the Human Environment and the Millennium and Sustainable Development Goals should also be included in sustainable infrastructure tools. Even though all principles and development goals are applicable worldwide, some of them should be specifically incorporated to frameworks focused on developing countries because of their distinctive context.

- The development of infrastructures may also trigger some interrelationships between social, economic and environmental risks, which were not included in the assessment because they overcome considerations of single projects. The long lifespan, broad spatial effects and inherent uncertainty of infrastructure projects mean that they often cause impacts that may be difficult to manage. Infrastructure projects are particularly susceptible to climate change and natural disaster risks that can be specially accentuated in the least developed countries. This component also serves to reaffirm the intimate linkage of all sustainable pillars (economy, environment, and society) to understand the meaning of Sustainability. The predominant role of one of these aspects in detriment of the rest can seriously affect the achievement of goals derived from the implementation of infrastructures in developing countries, where their own idiosyncrasies make them more vulnerable.

In summary, the increasing relevance of infrastructure in the least developing countries heightens the need for further analysis of their particular context, not only in order to redress the omission of the main site-specific issues in the conception of rating systems, but also the inclusion of sustainable impact assessments beyond the single project framework and the appropriate consideration of the development goals set by United Nations declarations.

\section{References}

[1] WCED, World Commission on Environment and Development (1987), Our common future, the report of the Brundtland Commission. Oxford: Oxford University Press. 
[2] Elkington, J. (1997). Cannibals with Forks: The Triple Bottom Line of 21st Century Business. Capstone.

[3] Pope J., Annandale D., \& Morrison-Saunders A. (2004). Conceptualising sustainability assessment. Environmental Impact Assessment Review, 24(6), 595-616.

[4] IPCC, Intergovernmental Panel for Climate Change (2007). Summary for policymakers, climate change. PICC WG1 Fourth Assessment Report, New York: Cambridge University Press.

[5] Devuyst, D. (2000). Linking impact assessment and sustainable development at the local level: the introduction of sustainability assessment systems. Sustainable Development, 8(2), 67-78.

[6] Ando S., Arima T., Bogaki K., Hasegawa H., Hoyano A., Ikaga T. et alter. (2005). Architecture for a sustainable future. Tokyo: Architectural Institute of Japan. in: The Future of Sustainable Construction 2003.

[8] Häkkinen T. (2007). Assessment of indicators for sustainable urban construction. Civil Engineering and Environmental Systems, 24(4), 247-259.

[9] LEED (Leadership in Energy and Environmental Design). www.usgbc.org/leed.

[10] CASBEE (Comprehensive Assessment System for Building Environmental Efficiency). www.ibec.or.jp/CASBEE/english/.

[11] BREEAM (Building Research Establish Environmental Assessment Method). www.breeam.com.

[12] EIA, Environmental Information Administration. (2008). EIA Annual Energy Outlook.

[13] Envision. http://www. sustainableinfrastructure.org.

[14] CEEQUAL. http://www.ceequal.com.

[15] IS (Infrastructure Sustainability Rating Tool). http://www.isca.org.au.

[16] UN, United Nations. (2008). World Urbanisation prospects: the 2007 revision population database.

http://www.un.org/esa/population/publications/wup2007/2007WUP Highlights web.pdf

[17] UNEP, United Nations Environment Programme - Sustainability Management and reporting. (2006). Benefits for Financial Institutions in Developing and Emerging Economies.

[18] Berardi, U. (2015). Assessing and Measuring Environmental Impact and Sustainability. Chapter 15, Sustainability assessments of buildings, communities and cities, 497-545. Ed. Jiri Jaromir Klemes, Elsevier. [19] SDSN, Sustainable Development Solutions Network Thematic Group on Sustainable Cities supported by UN-Habitat, the Global Network of Cities, Local and Regional Governments (UCLG), Cities Alliance and Local Governments for Sustainability (ICLEI). (2013). Why the world needs an urban sustainable development goal. http://unsdsn.org/resources/publications/why-the-world-needs-an-urban-sustainable-development-goal/ [20] UN Habitat. (2007). Inclusive and Sustainable Urban Planning: A guide for Municipalities. Volume 4: Sustainable Action Planning. http://unhabitat.org/books/inclusive-and-sustainable-urban-developmentplanning-a-guide-for-municipalities-volume-4l

[21] UNCTAD, United Nations Conference on Trade and Development. (2014). World Investment report in 2014. Investing in the SDGs: An Action Plan. New York and Geneva 2014. http://unctad.org/en/PublicationsLibrary/wir2014 en.pdf

[22] Haapio, A. (2012). Towards Sustainable urban communities. Environ. Impact Assess. Rev. 32(1), 165169.

[23] BREEAM Communities. (2009). Technical Manual. BREEAM Communities Assessor Manual Development Planning Application Stage SD5065B, BRE Global Ltd. Glasgow, UK.

[24] CASBEE for Urban Development. (2007). Technical Manual. Institute for Building Environment and Energy Conservation, Japan.

[25] LEED for Neighbourhood Development. (2009). Manual, The US Green Building Council.

[26] European Union Regional Policy. (2009). Promoting Sustainable Urban Development in Europe.

Achievements and

Opportunities. http://ec.europa.eu/regional policy/sources/docgener/presenta/urban2009/urban2009 en.pd f

[27] Ugwu, O.O. and Haupt, T.C. (2005). Key performance indicators for infrastructure sustainability - a comparative study between Hong Kong and South Africa. Journal of Engineering, Design and Technology, 3(1), 30-43. 
[28] UN Habitat. (2015). E-Governance and Urban Policy Design in Developing

[29] Fardoust S., Yongbeom K. and Paz-Sepulveda C. (2010). Post-crisis Growth and Development: A Development Agenda for the G-20. World Bank Publications.

[30] Hiremath, R.B., Balachandra, P., Kumar, B., Bansode, S.S., Murali, J. (2013). Indicator-based urban sustainability- a review. Energy for Sustainable Development 17(6), 555-563.

[31] Watkins, G. (2014). Approaches to the Assessment and Implementation of Sustainable Infrastructure Projects in Latin America and the Caribbean. Inter-American Development Bank. Environmental Safeguards Unit (VPS/ESG) Technical Note No. IDB-TN-739. [32] Berardi, U. (2013). Sustainability assessment of urban communities through rating systems. Environ. Dev. Sustainability 15(6), 1573-1591. [33] UN, United Nations Conference on Environment and Development. (1992). Rio Declaration on Environment and Development. http://www.un.org/documents/ga/conf151/aconf15126-1annex1.htm [34] Millennium Summit. (2000). UN Millennium Declaration. (2000). http://www.un.org/es/millenniumgoals/ [35] UN Habitat. (2015). Transforming our world: The 2030 Agenda for Sustainable Development. https://sustainabledevelopment.un.org/post2015/transformingourworld

\section{Guidelines.}

